\title{
Elogio do anacronismo: para os andróginos de Ismael Nery
}

\author{
Maria Bernardete Ramos Flores*
}

\section{RESUMO}

"Por que fazer o elogio do anacronismo quando se é historiador?" — perguntou Loraux. O anacronismo, que já foi o pecado dos historiadores, hoje se impóe. Numa abordagem inspirada por alguns filósofos contemporâneos, tais como Agamben, Rancière e Didi-Huberman, que instigam em nosso pensamento uma nova concepção de tempo, este artigo desenvolve argumentos para demonstrar que Ismael Nery (1900-1934), o "artista maldito" do modernismo brasileiro, pode ser tomado como um artista anacrônico, pelo fato de configurar montagens temporais em sua arte (pintura, desenho e poesia) para expressar um dos princípios de seu sistema filosófico: a abstração do tempo e do espaço. A arte de Ismael apresentou-se como universal, mística e espiritual, o que o deixou fora do seu tempo, ou melhor, fora da estética da representação chamada para dar visibilidade aos temas do nacional.

Palavras-chave: tempo; anacronismo; arte; modernidade; misticismo; androginia.

\section{ABSTRACT}

"Why praise anachronism when we are historians?" - asked Loraux. Anachronism was once a sin for historians, but has become a necessity. Approaching the issue from the perspective of some contemporary philosophers, such as Agamben, Rancière and Didi-Huberman, who rouse in our thought a new conception of time, this article argues that Ismael Nery (1900-1934), the "damned artist" of Brazilian Modernism, can be taken as an anachronistic artist. His art (painting, drawing and poetry) sets up temporal collages to express one of the principles of his philosophical system: the abstraction of time and space. The art of Nery presented itself as universal, mystical and spiritual, what placed him out of his time, or rather, out of the aesthetic representation that had been called upon to give visuality to the themes of the national.

Keywords: time; anachronism; art; modernity; mysticism; androgyny. dade do CNPq, nível 1C. Professora titular na Universidade Federal de Santa Catarina (UFSC). Florianópolis, SC, Brasil. E-mail: mbernaramos@gmail.com. 
— Podemos ser contemporâneos de todos os seres humanos?

— Sim, graças ao pensamento, ou à obra de arte, à literatura. Eu olho um quadro de Velázquez e me transformo em contemporâneo de Velázquez.

— Então é uma contemporaneidade truncada. Você é contemporâneo de Velázquez, mas ele não o é de você.

- Você se equivoca, Federico, Velázquez é seu quadro. Eu olho o quadro, e o quadro olha a mim. Vou mais longe. As meninas. Está pintando-as Velázquez. Mas as figuras do quadro não olham para o pintor. Todos nos olham para nós. Nós nos convertemos em parte do quadro, e o quadro em parte de nós... ${ }^{1}$

No romance-ensaio Federico em sua sacada, de Carlos Fuentes, num extremado experimentalismo literário, acompanhamos o diálogo entre Dante Loredano e Federico Nietzsche, que refletem sobre a cidade incendiada por uma violenta revolução, como se esta fosse uma síntese de todas, desde a francesa até a cubana. Carlos Fuentes, ao configurar numa ficção a teoria do eterno retorno de Friedrich Nietzsche, produz um encontro de personagens desencontradas e consegue tornar plausível a noção de que as ambiçóes humanas, sempre nos mesmos jogos de poder, e os sonhos de amor e justiça, não param de se insurgir na vida do homem. Como é sabido, Nietzsche concebe o mundo enquanto criação e destruição permanentes; tudo retorna sem cessar. Nesta imaginação nietzschiana, os fatos históricos aparecem como hóspedes indesejáveis, distantes e incoerentes, um cambiante lastro que ameaça em dar a volta à vida, com seu peso morto. O filósofo alemão defende a tese de que se o universo tivesse algum objetivo, já o teria atingido; se tivesse alguma finalidade, já a teria realizado. ${ }^{2}$

Chamamos a atenção, no diálogo que consta como epígrafe, para a conjectura de que podemos ser contemporâneos de todos os seres humanos graças ao pensamento, à arte e à literatura (grifo meu). Somos contemporâneos de Velázquez assim como Velázquez é nosso contemporâneo. A contemporaneidade entre dois seres — Velázquez e nós — tão distantes temporalmente desconcerta a noção de história cara à École des Annales. "A história é a ciência dos homens no tempo", afirmava Marc Bloch, que, para ilustrar sua tese, lançava mão do provérbio árabe: "Os homens se assemelham mais ao seu tempo do que aos seus pais." Jacques Rancière cita esta passagem de Bloch para mostrar que nesta perspectiva o anacronismo foi o pecado mortal dos historiadores. Mas, o "anacronismo" assim concebido é anti-histórico. ${ }^{3} \mathrm{Ou}$, numa outra forma de colocar a questão, “o medo do anacronismo é

\footnotetext{
${ }^{1}$ FUENTES, Carlos. Federico em sua sacada. Tradução Carlos Nougué. Rio de Janeiro: Rocco, 2013. p. 86.

2 MARTON, Scarlet. Extravagâncias: Ensaios sobre a filosofia de Nietzsche. São Paulo: Discurso Editorial; Unijuí, 2000. p. 78.

${ }^{3}$ RANCIÈRE, Jacques. O conceito de anacronismo e a verdade do historiador. Traduçáo Mônica Costa Netto. In: SALOMON, Marlon (Org.). História, verdade e tempo. Chapecó: Argos, 2011. p. 21-50; p. 35; 47.
} 
bloqueador", nos diz Nicole Loraux. ${ }^{4} \mathrm{E}$ a autora chama atenção para duas passagens de Bloch que constam do seu Apologia para a história, as quais abalam a certeza quanto ao método que condenou o anacronismo. A primeira refere-se a uma suspeita: "Existe, [no entanto] na natureza e nas sociedades um fundo permanente, sem o qual os nomes de homem e de sociedade não diriam nada." A segunda refere-se a uma fórmula: "É preciso compreender o presente pelo passado e o passado pelo presente."

Parece que a reflexão sobre o anacronismo, hoje, se impóe. Quando o trabalho da memória sai do âmbito da psique e invade a cena política, quando nos deparamos com uma "verdadeira sedução pela memória", ${ }^{6}$ nos vemos diante da "obrigaçáo" de inventarmos novos modos de ler o passado. Desde as últimas décadas do século XX, assistimos aos fenômenos de afirmação de identidades legitimadas pelo passado, como se este fosse um bem a ser "resgatado"; povos reivindicam direitos em nome da história; erguem-se monumentos à memória em toda a parte; museus de tudo são criados; "cascos" históricos urbanos são montados ao gosto dos turistas; livros de memórias e de testemunhos são bem aceitos pelo mercado. Para François Hartog, a consequência mais forte disso é a estranha sensação de que vivemos um onipresente que, de um lado, nos tira a coragem e a crença de antever o futuro e, de outro, perdemos também a ambição de abandonar, de superar o passado e de nos distanciar dele. ${ }^{7}$

Paul Ricoeur também se debruçou sobre a mesma questáo. Ao interpretar a Segunda consideração intempestiva de Nietzsche, chama a atenção para o tema do "excesso de história" nos dias de hoje. ${ }^{8}$ Ricoeur diz que a percepção de um "excesso de história", tal como tratado por Nietzsche, faz eco com o Fedro, de Platão. Se neste havia desconfiança com a escrita como pharmakon, hesitante entre veneno e remédio na morte da memória, para Nietzsche, "história demais mata o homem". ' Contudo, se é "verdade que o excesso de conhecimentos históricos prejudica o ser vivo, também é necessário entender que a vida precisa do serviço da história." ${ }^{\prime 10}$ Frase um pouco modificada da epígrafe da Tese 12 de Sobre o conceito da história, de Walter Benjamin: "Precisamos da história, mas não como precisam dela os ociosos que passeiam no jardim da ciência." ${ }^{" 11}$ Benjamin encabeça sua tese com esta citação de Nietzsche para dar o tom a sua concepção de história: necessitamos da história, mas não daquela que

\footnotetext{
${ }^{4}$ LORAUX, Nicole. Elogio do anacronismo. In: NOVAIS, Adauto (Org.). Tempo e História. São Paulo: Companhia das Letras, 1992. p. 57-70.

${ }^{5}$ Ibid, p. 61.

${ }^{6}$ HUYSSEN, Andreas. Seduzidos pela memória. Rio de Janeiro: Aeroplano, 2004.

${ }^{7}$ HARTOG, François. Tempo e Patrimônio. Vária História, Belo Horizonte, v. 22, n. 36, p. 261-273, jul./ dez. 2006.

${ }^{8}$ RICOEUR, Paul. A memória, a história, o esquecimento. Tradução Alain François. Campinas: Unicamp, 2007. p. 303.

${ }^{9}$ Ibid, p. 305.

${ }^{10}$ Ibid, p. 305.

${ }^{11}$ BENJAMIN, Walter. Sobre o conceito de história. In: Obras escolhidas: Magia e Técnica, Arte e Política. Tradução Sérgio Paulo Rouanet. São Paulo: Brasiliense, 1987. p. 228.
} 
deva dar razão ao presente. Pelo contrário, ela deve ser intempestiva, andar na contramão, que anime a vida. É fazer a história a contrapelo.

Giorgio Agamben, ao inserir-se nesse debate, parte também da Segunda consideração intempestiva, "com as quais Nietzsche quis acertar as contas com o seu tempo, tomar posição em relação ao presente". Agamben considera que aqueles que aderem plenamente a sua época não são contemporâneos porque, por manter os olhos fixos nela, não conseguem enxergá-la.

Pertence verdadeiramente ao seu tempo aquele que não coincide perfeitamente com este, nem está adequado às suas pretensóes e é, portanto, nesse sentido, inatual; mas, exatamente por isso, exatamente através deste deslocamento e desse anacronismo, ele é capaz, mais do que outros, de perceber e apreender o seu tempo. ${ }^{12}$

A contemporaneidade, segundo o filósofo italiano, é uma singular relação com o presente, que adere a este e, ao mesmo tempo, dele se distancia, através de "uma dissociação e de um anacronismo". O tema do anacronismo torna-se, então, promissor para pensarmos uma nova maneira de lidar com o tempo na história; uma maneira que descubra, nas profundezas da história, a matéria estratificada anacronicamente a qual religa o espírito humano; uma maneira que considere a montagem de tempos, as múltiplas temporalidades que se imiscuem na configuração de um acontecimento histórico. "A história é objeto de uma construção cujo lugar não é o tempo vazio e homogêneo, mas um tempo saturado de 'agoras."."13

O filósofo e historiador da arte Georges Didi-Huberman tem dedicado boa parte de suas pesquisas a demostrar que no campo do verificável não se trata exatamente de datas para se lidar com o anacronismo. Trata-se de uma dimensão do tempo, "uma irrupção ou aparição do tempo, da qual falaram tão bem Proust e Benjamin sob a denominação de 'memória involuntária”, ou daquela memória que “é psíquica”, lembrando Freud, “em seu processo, anacrônica em seu efeito de montagem, de construção ou da 'decantação' do tempo". ${ }^{14} \mathrm{O}$ historiador, segundo Didi-Huberman, não pode se contentar em fazer a história da arte apenas sob o ângulo da euchronie, isto é, o ângulo conveniente do artista e seu tempo. Ao estudar a obra de Fra Angelico, por exemplo, ele foi atraído por um afresco quase desconhecido na

\footnotetext{
${ }^{12}$ AGAMBEN, Giorgio. O que é o contemporâneo. Tradução Vinícios N. Honesko. Chapecó, SC: Argos, 2009. p. 58.

${ }^{13}$ BENJAMIN, Sobre o conceito de história, op. cit., p. 229. No Brasil Jetztzeit é traduzido por "agora”, considerando que na versão francesa Benjamin usara a palavra "présent", assim, entre aspas, para dar a entender que se trata de um agora singular, pois se refere à capacidade de presente que o passado tem. Cf. MATE, Reyes. Meia-noite na história. Comentários às teses de Walter Benjamin. Tradução Nélio Schneider. São Leopoldo, RS: Unisinos, 2011. p. 289.

${ }^{14}$ DIDI-HUBERMAN, Georges. Ante el tempo. Historia del arte y anacronismo de las imágenes. Tradução Antonio Oviedo. Buenos Aires: Adriana Hidalgo, 2011. p. 44 e 60. "una irrupción o aparición del tempo, aquello de lo cual hablaron tan bien Proust e Benjamin bajo la denominación de 'memoria involuntaria” [...] "es psíquica" [...] "en su proceso, anacrónica en sus efectos de montaje, de reconstrucción o de la 'decantación' del tempo".
} 


\section{ElOGIO DO ANACRONISMO: \\ PARA OS ANDRÓGINOS DE ISMAEL NERY}

Maria Bernardete Ramos Flores

história da arte, a Santa conversação (1438-1450), que se assemelha aos drippings de Pollock. Esta semelhança — alerta Didi-Huberman — não quer dizer nem que Fra Angelico fora um precursor de Pollock e nem que este copiara o artista do renascimento italiano, ou que nele se tenha inspirado. A "semelhança deslocada", como verificada, exigiu procedimentos metodológicos que não se apoiassem apenas no factual ou no contextual. A Santa Conversação de Fra Angelico configura a interpretação específica de uma tradição textual na biblioteca do convento de Sáo Marco, onde vivia o artista dominicano, lugar já por excelência anacrônico por guardar o pensamento de todos os tempos: "diecinueve siglo ao menos". ${ }^{15}$

\section{Um artista anacrônico}

Tal visualidade exige que se lo examine bajo el ángulo de su memoria, es decir, de sus manipulaciones del tiempo, cuyos hilos nos descubren mejor a un artista anacrónico, a un 'artista contra su tiempo.'16

Como hipótese, aqui neste artigo, vamos refletir sobre o uso da noção de anacronismo na abordagem da obra (pintura, desenho e poesia) de Ismael Nery (1900-1934), ${ }^{17}$ obra que hoje é vista como "a mais singular no contexto do período modernista brasileiro", ${ }^{18}$ mas que à época de sua produção (década de 1920) fora praticamente desconhecida. ${ }^{19}$ Ismael Nery foi considerado o "pintor maldito", ${ }^{20}$ não só porque morreu cedo e pouco conhecido, mas por ter tomado distância do modernismo hegemônico, dedicado à estética da representação para dar visualidade a temas de caráter nacional. ${ }^{21} \mathrm{~A}$ composição com figuras humanas (fratura-

\footnotetext{
${ }^{15}$ Ibid, p. 43.

${ }^{16}$ Ibid, p. 43.

${ }^{17}$ Para visualizar obras de Ismael Nery, remeto às seguintes obras: Catálogo: Ismael Nery — 50 anos depois. Curadoria: Aracy Amaral. São Paulo: Museu de Arte Contemporânea da Universidade de São Paulo, 1984. Catálogo: Ismael Nery - 100 anos: a poética de um mito. Curadoria: Denise Mattar. São Paulo: Fundação Armando Álvares Penteado, 2000. Catálogo: Ismael Nery. Organização e Curadoria: Denise Mattar. Rio de Janeiro: Banco Pactual S.A./Lei de Incentivo à Cultura/Ministério da Cultura, 2004. Encontram-se, igualmente, muitas reproduçóes no site:

$<$ http://www.itaucultural.org.br/aplicExternas/enciclopedia_IC/index.cfm?fuseaction=artistas_obras\&cd_ verbete $=900 \&$ cd_idioma $=28555>$.

${ }^{18}$ AMARAL, Aracy. Textos do Trópico de Capricórnio. São Paulo: Ed. 34, 2006. v. 1, p. 74.

${ }^{19}$ A obra de Ismael Nery, quando vivo, fora conhecida apenas por um grupo restrito de modernistas cariocas; após sua morte, em 1934, fora totalmente esquecida, vindo a "ressuscitar" na década de 1960, quando o tema nacional próprio da visualidade brasileira da primeira metade do século fora abandonado, e, especialmente, quando novos estudos sobre o modernismo brasileiro perceberam que, por "baixo" do "programa" consagrado pela história, paulista e nacionalista, houve experimentalismos estéticos diversos.

${ }^{20}$ BENTO, Antônio. Ismael Nery. São Paulo: Gráficos, 1993. p. 9.

${ }^{21}$ CHIARELLI, Tadeu. Pintura não é só beleza. A crítica de arte de Mário de Andrade. Florianópolis: Letras Contemporâneas, 2007. p. 257.
} 
das, justapostas, de caráter atemporal e universal, em estilos fisionômicos que se repetem) foi o objeto principal de sua arte. A arte, para Nery, servia-lhe como meio para expressar ideias do seu sistema visionário e místico. Ele estreitava laços entre arte e religião, entre estética e misticismo; via o corpo como molde da alma; baseado no tomismo acreditava numa unidade divina na qual toda a humanidade e cada um fazia parte dela, confrontada constantemente com o criador. Para ele, todo homem encerra, potencialmente, a divindade. "Sou um germe de um Deus, toda gente o é também" (Poema, 1933).

Tentarei, portanto, mostrar que Ismael foi um artista anacrônico, por conter dimensões que fogem do ângulo puramente de seu tempo. Já na própria obra, podemos perceber montagens de tempos, como se o artista quisesse dar plasticidade à sua crença de que "Tudo foi feito no princípio - porém tudo só existirá realmente em tempos diversos." (Testamento espiritual de Ismael Nery, 1933). No desenho O pecado, s.d., de Ismael Nery, vemos em primeiro plano a imagem do paraíso no momento da queda. Uma serpente oferece a maçã a Eva, enquanto Adão dorme deitado na relva. Ao largo deste mundo idílico, juntam-se à composição do cenário imagens de chaminé, edifício, torres de aço, carro, avião, zepelim e o que parece ser um navio ao fundo, numa justaposição de temporalidades históricas. $\mathrm{O}$ espectador, para apreender a fatura da obra, precisa "descer às profundezas" da história e encontrar as referências culturais que povoaram a imaginação do artista. E não é apenas o trabalho plástico de Ismael que encerra anacronias, pela montagem de tempos heterogêneos. Ele também foi um artista anacrônico naquela perspectiva de Agamben: a contemporaneidade de Ismael Nery é feita de uma singular "relação com o tempo que a este adere através de uma dissociação e um anacronismo". ${ }^{22}$ Veremos, no decorrer deste artigo, que Ismael ficou distante da arte que se praticava no Brasil por aderir ao movimento do revival espiritual empreendido por correntes artísticas e intelectuais europeias, para romper com o curso materializante da humanidade.

Pela leitura dos depoimentos de seus contemporâneos ${ }^{23}$ e dos estudos mais recentes, de historiadores e críticos de arte, sabe-se que Ismael Nery era católico, o que era estranho entre os intelectuais modernos. ${ }^{24}$ Os amigos o consideravam dotado de muitas habilidades: pintor, desenhista, arquiteto, cenógrafo, estilista, dançarino e poeta; filósofo, teólogo, religioso e místico; a imagem que ficou dele é a de um dândi, polemista, conversador; como artista, é apontado como surrealista e um dos pioneiros da pintura metafísica, ao lado de

\footnotetext{
${ }^{22}$ AGAMBEN, Giorgio. O que é o contemporâneo, op. cit., p. 59.

${ }^{23}$ A partir da "descoberta", a obra de Ismael surpreendeu colecionadores, críticos de arte e historiadores. O catálogo de 1984 traz vários depoimentos da geração modernista carioca que convivera com o artista.

${ }^{24}$ Os católicos, entre fins de 1920 e 1940, no Rio de Janeiro, podem ser classificados em duas correntes: de um lado, os animados por Jackson de Figueiredo e Alceu Amoroso Lima, que militavam no Centro Dom Vital e na Revista $A$ Ordem, e, de outro, a tríade composta por Ismael Nery, Murilo Mendes e Jorge de Lima, que faziam do catolicismo um tema e uma forma artístico-literária. Cf. PINHEIRO FILHO, Fernando Antonio. El modernismo y la formación del intelectual católico en el Brasil. In: ALTAMIRANO, Carlos. Historia de los intelectuales en América Latina II. Buenos Aires: Katz Editores, 2010. p. 325.
} 
Giorgio de Chirico. Ismael fez duas viagens a Paris. Na primeira, em 1921, matriculou-se na Academia Julian. O contato com os museus, em Paris e Roma, e com a linguagem artística moderna deixaram-lhe marcas. É possível identificar em seus trabalhos aspectos que remetem aos pré-rafaelitas, à linha sinuosa de Aubrey Beardley, aos simbolistas, ao cubismo de Picasso, há referências aos paradoxos de Magritte, à bidimensionalidade matissiana e às composições surrealistas. Na segunda viagem a Paris, em 1927, encontrou-se com Breton e tornou-se amigo de Marc Chagall, fato que refletiu em várias de suas figuras flutuantes e oníricas.

Figura 1. Autorretrato, 1927, óleo s/tela, 129/83 cm, col. Domingos Giobbi, SP.

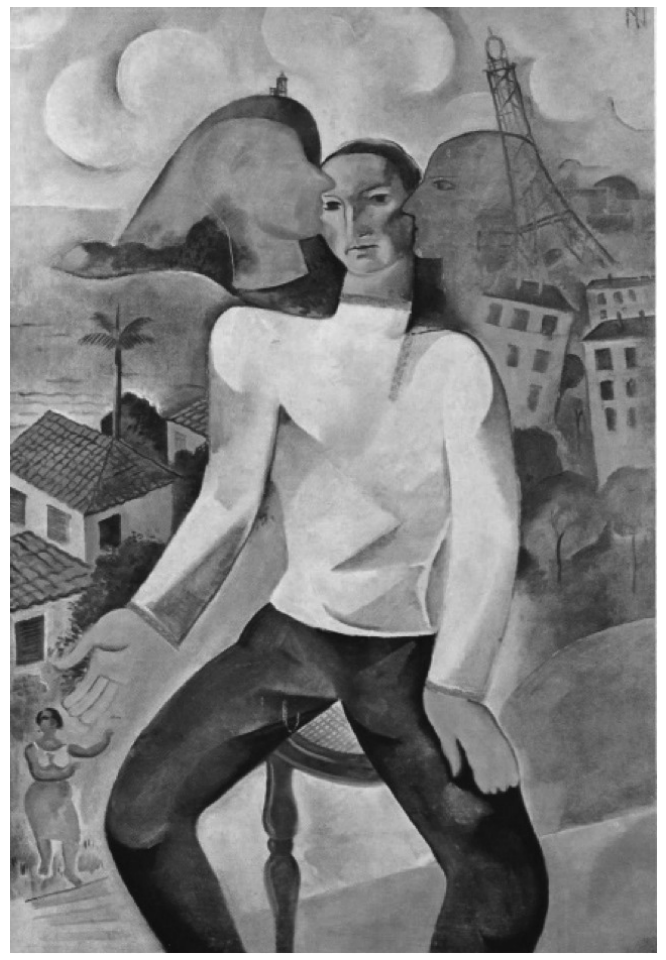

Fonte: Catálogo, 1987, p. 172.

No Autorretrato de IN - 1927 (figura 1), vemos no centro do quadro a figura de Ismael sentado numa cadeira flutuante que divide o quadro em dois espaços: à direita, uma paisagem parisiense com a Torre Eiffel e, à esquerda, o Pão de Açúcar representa a paisagem carioca. Sobrepostos à Torre Eiffel e ao Pão de Açúcar, perfis de Ismael refletidos no mesmo nível do seu rosto. Uma concomitância temporal e espacial para expressar sua ideia de tempo e espaço. Em anexo à pintura, um pequeno texto que diz: 
Abstração do tempo é necessária pelo fato da vida ser dinâmica, isto é, existir o movimento e a evolução. Um homem que se estudar em um momento, não se conhecerá. O presente de um homem é porém um resultado do seu passado e do de seus antepassados. ${ }^{25}$

Tanto na imagem quanto no adendo encontra-se a síntese do pensamento filosófico de Ismael. "O presente de um homem é porém um resultado de seu passado e do de seus antepassados". No seu sistema de pensamento, denominado Essencialismo, ${ }^{26}$ expresso nas conversas com os amigos, nos poemas ${ }^{27}$ e, especialmente, na obra plástica, a abstração do tempo e do espaço era um dos princípios. Para Ismael Nery, a humanidade era composta de todos os homens que nasceram e dos que ainda nascerão. "Para mim eu ainda não acabei de nascer. / Tenho mães pequeninas ou que ainda não nasceram”. (Poema Eu, 1933). "Desde Eva que tu te repetes em formas inúteis / Ainda não atinastes, ó mulher! / Os filhos das minhas noras se parecem com a avó”. (Poemas pré-essencialista, 1932). ${ }^{28}$ Parece que ouvimos nestes versos ecos da Tese 2 de Sobre o conceito de história: "Alguém na terra está à nossa espera", pois, "Não existem nas vozes que escutamos, ecos de vozes que emudeceram? Não têm as mulheres que cortejamos irmãs que elas não chegaram a conhecer? Se assim é, existe um encontro secreto marcado entre as geraçóes precedentes e a nossa." ${ }^{29}$

Acreditava Ismael que o espírito do homem moderno caracterizava-se, sobretudo, pelo cansaço diante da ideia de um tempo progressivo e linear, que traz no seu bojo a corrupção e a destruição. "O homem agora distribui suas esperanças na arte e na ciência. Chegará um tempo em que a arte e a ciência não bastarão para suprir a ânsia crescente de compreensão que a humanidade tem" (Testamento...). Murilo Mendes registra um fragmento de notas deixado por Ismael, bastante elucidativo de sua noção de tempo:

As teorias políticas são todas feitas dentro da ideia de tempo (...) O erro dos ângulos só poderá ser anulado com uma volta à raiz (...) Estudando-se a totalidade desses momentos chega-se à conclusão de que verdadeiramente o homem não se pode representar nem ser representado com as perspectivas de um só momento (...) A vida humana possui as mesmas características de um homem (...). ${ }^{30}$

\footnotetext{
${ }^{25}$ BURLAMAQUI, Jorge. Abstração do tempo e do espaço. A Ordem, Rio de Janeiro, p. 193-195, fev./mar. 1935.

${ }^{26} \mathrm{O}$ poeta Murilo Mendes, o amigo mais próximo de Ismael, publicou 17 crônicas em O Estado de S. Paulo, de julho de 1948 a janeiro de 1949, as quais foram reunidas mais tarde e publicada em livro sob o título Recordaçóes de Ismael Nery. A edição de 1996 traz um excelente prefácio de Davi Arrigucci Jr.

${ }^{27}$ Os poemas e textos de Ismael Nery foram recolhidos por Murilo Mendes e publicados pela primeira vez, na revista $A$ Ordem de 1935. Hoje, encontram-se reproduzidos nos vários catálogos da obra do artista e diversos sites.

${ }^{28}$ Todos os fragmentos de poemas citados foram extraídos do Catálogo, 1984.

${ }^{29}$ BENJAMIN, Walter. Sobre o conceito de história, op. cit., p. 223.

${ }^{30}$ MENDES, Murilo. Recordações de Ismael Nery. São Paulo: USP/Giordano, 1996. p. 53.
} 


\section{ElOGIO DO ANACRONISMO: \\ PARA OS ANDRÓGINOS DE ISMAEL NERY}

Maria Bernardete Ramos Flores

Parece-nos razoável fazermos desta consciência da herança dos antepassados analogias com a concepção de tempo proposta por Benjamin, para quem o passado não é um tempo concluído, o passado não está amortizado no presente. "O historiador consciente disso renuncia a desfiar entre os dedos os acontecimentos, como as contas de um rosário." ${ }^{31}$

Para Ismael Nery, a angústia que a humanidade vinha carregando era herança dos antepassados. "Herdei de meus pais e de meus avós / e aumentará em meus filhos / e se tornará universal / desde o dia em que Caim assassinou Abel" (Fragmentos do meu poema, 1933). Assim, a geração de avós espera que a geração de netos interrompa a transmissão desta agonia e faça surgir a esperança. "Todo o homem recita um poema nas vésperas da sua morte - a humanidade recitará também o seu nas vésperas da sua, pela boca de todos os homens que nesse tempo serão poetas" (Testamento espiritual de Ismael Nery, 1933). Ismael acreditava que no futuro todos os homens seriam poetas, como Cristo, fato que elevaria a humanidade a uma ordem superior e a salvaria da fragilidade e da miséria que vinham do pecado original. O erro só poderia ser anulado com uma volta à raiz, ao tempo da origem, quando Deus se movia com liberdade.

Acabaram-se os tempos.

Morreram as árvores e os homens,

Destruíram as casas

Submergiram as montanhas

Depois o mar desapareceu

O mundo transformou-se numa enorme planície

Onde só existe areia e uma tristeza infinita.

Um anjo sobrevoa os destroços da terra,

Olhando a cólera de um Deus ofendido.

(Poema para ela, 1933)

De fato, Ismael desenha o Anjo do apocalipse (figura 2). O anjo encontra-se de cócoras num pedestal erguido numa paisagem urbana identificada por traços que remetem a prédios. A cabeça do anjo está virada para trás e ele olha do alto, pelas costas, na direção da terra. À sua frente, uma das mãos repousa sobre um dos joelhos e a outra, espalmada, faz um gesto estendido para o alto em direção ao céu, tocando as nuvens. O movimento do Anjo do apocalipse de Ismael quase lembra o do Angelus Novus de Klee, analisado por Walter Benjamin. O anjo de Ismael não tem os olhos "escancarados" e a boca "dilatada", não traz a fisionomia de horror "dirigida para o passado", mas, vira-se para trás e olha

${ }^{31}$ BENJAMIN, Walter. Sobre o conceito de história, op. cit., p. 232. 
lá embaixo. Parece que observa os "destroços da terra" narrados no poema. Se o anjo de Benjamin/Klee, ao olhar para a frente, vê um futuro que ele gostaria de deter, o anjo de Nery parece querer levar a humanidade para fora do mundo terreno, no gesto do braço estendido a indicar o caminho. No seu Poema pós-essencialista (1931) ele escreve que certo dia parou e se pôs a refletir. Olhou para o longo caminho percorrido e não viu mais que o seu próprio rastro. Tudo pavorosamente desabitado. Nem leóes nem elefantes nos desertos da África. Nem pirâmides no Egito e nem a Torre Eiffel em Paris. Somente a consciência da sua própria existência, numa ideia inversa a que chama mulher e que paira rarefeita sobre a superfície do globo. Mas volta a percorrer em pensamento o espaço. Agora vê que os mares são profundos, as montanhas reapareceram, tais como os elefantes e os leóes nos desertos da África...

Figura 2. Anjo do apocalipse, s.d., nanquim s/papel, 25,2×20 cm, col. Laertes M. Ferrão, SP.

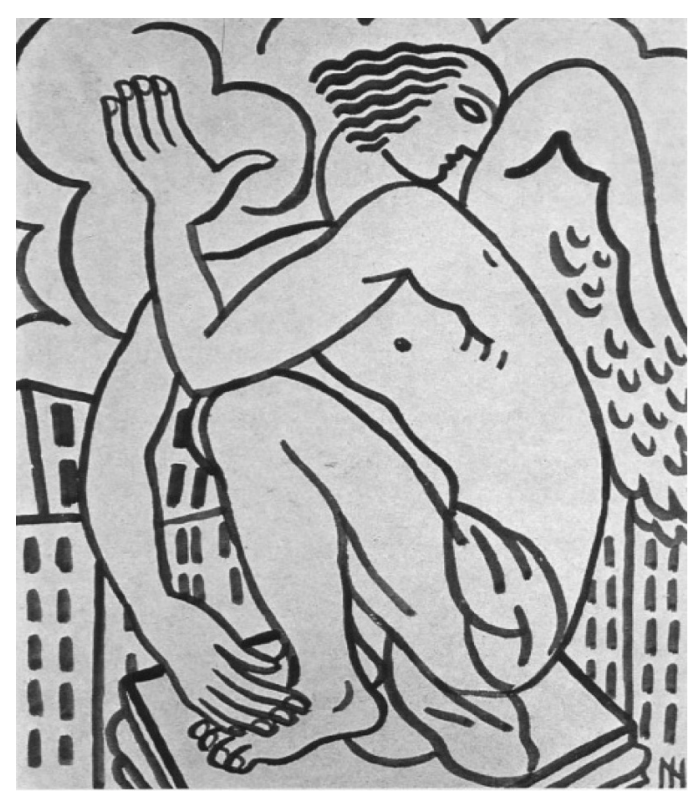

Fonte: Catálogo, 1987, p. 207.

Construíram as pirâmides no Egito e levantaram a Torre Eiffel em Paris no ano em que um outro Eu nascia em Belém do Pará. ${ }^{32}$ Tudo se povoou transbordantemente. Acho-me agora sentado na prisão, olhando sereno através das grades, aguardando o julgamento do crime nefando que cometi de usar a mim mesmo na minha mãe, mulher, filha, neta, bisneta, tataraneta, nora e cunhada. Voltarei ainda uma vez para ser o meu juiz.

\footnotetext{
${ }^{32}$ Ismael nasceu em Pará, em 1900. A Torre Eiffel foi inaugurada em 1889.
} 


\section{ELOGIO DO ANACRONISMO: \\ PARA OS ANDRÓGINOS DE ISMAEL NERY}

Maria Bernardete Ramos Flores

São imagens que nos reportam à Tese 3 de Benjamin, o grande inspirador dos filósofos que tentam hoje pensar uma noção de tempo que afaste da cronologia linear do progresso: "Somente para a humanidade redimida o passado é citável, em cada um dos seus momentos. Cada momento vivido transforma-se numa citation à l'ordre du jour - e esse dia é justamente o dia do juízo final."33

\section{O retorno do andrógino}

Diante de uma imagem, não se deve perguntar somente que história ela documenta e de que história ela é contemporânea, mas também: que memória ela (a imagem) sedimenta, de que recalque ela é o retorno. ${ }^{34}$

O Anjo do apocalipse, que vimos anteriormente, é uma figura masculina. Mas a androginia é uma das marcas da obra de Ismael. Em vários de seus autorretratos, ele se pinta femininamente. No pequeno Autorretrato (1925), o artista aparece com uma blusa larga, encarando o observador como se estivesse por trás de um parapeito sobre o qual repousa a mão esquerda, a mão direita com um anel redondo espalmada no peito, os dedos longos, as unhas pintadas, a boca de batom, os olhos rasgados, os cabelos armados num caimento. Em Mulher sentada com ramos de flores (1927), o quadro com a maior sensualidade feminina da fatura de Ismael, o rosto tem a mesma fisionomia dos seus autorretratos. Em $N u$ ajoelhado (s/d), apesar da feminilidade definida pelos seios salientes, a musculatura é tipicamente masculina e o rosto alude aos traços fisionômicos de Ismael. No quadro Andrógino (s/d), ${ }^{35}$ uma linha vertical divide o rosto da figura. A metade masculina joga com a fisionomia dos seus autorretratos; a outra metade lembra o de Adalgisa, sua esposa. No Autorretrato Cristo (s/d) Ismael sobrepõe suas feições à imagem de um Cristo andrógino.

\footnotetext{
${ }^{33}$ BENJAMIN, Walter. Sobre o conceito de história, op. cit., p. 223.

${ }^{4}$ DIDI-HUBERMAN, Georges. La condition des images. Entretian avec Frédéric Lambert et François Niney. 2007. p. 12. Tradução livre. Disponível em: <http://documents.irevues.inist.fr/bitstream/handle/2042/28239/2007_19_06.pdf?sequence=1>. Acesso em: 28 jan. 2014. "Devant d'ne image, il ne faut pas seulement se demander quelle histoire elle documente et de quelle histoire elle est contemporaine, mais aussi: que mémoire elle sédimente, de quel refoulé elle est le retour."

${ }^{35}$ Tratei do quadro Andrógino no artigo Androginia e Surrealismo a propósito de Frida e Ismael: velhos mitos eterno feminino, a sair pela Revista de Estudos Feministas, Florianópolis.
} 
Figura 3. Andrógino, s.d., aquarela s/papel, $27 \times 18,5 \mathrm{~cm}$, col. Luis Fernando Nazarian, SP.

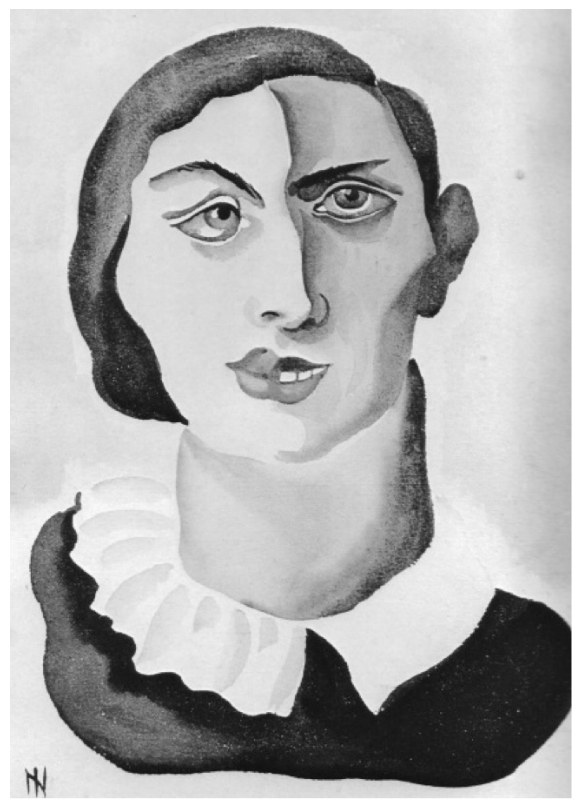

Fonte: Catálogo, 1984, p. 115.

A hipótese que se levanta é a de que Ismael resolve plasticamente a simbologia do andrógino ressurgida nas artes, entre os pré-rafaelitas, os simbolistas e mais tarde entre os surrealistas. Procedendo-se a um "rastreamento" da imagem da androginia, iconográfica e literária, concebe-se que a androginia em Ismael Nery, na sua experimentação estética, remonta à simbologia do andrógino, por vezes, ao mito platônico que havia sido atualizado pelo surrealismo de Breton, no qual um homem está condenado desde o nascimento a encontrar a mulher, sua metade perdida. ${ }^{36} \mathrm{O}$ momento do encontro é o momento da fusão total, unidade integral, orgânica e psíquica. Outras vezes, se percebe nos andróginos de Ismael referências ao mito da "unidade primordial" que existira no mundo antigo e primitivo. O movimento de retorno do mito fora inspirado no Renascimento italiano. Os fenômenos de mudança histórica pelos quais atravessava a Europa de fin-de-siécle, a consciência do declínio do Ocidente e os sonhos de uma nova era despertaram interesse por outros processos históricos que haviam passado por período de transição. O Renascimento italiano fascinava como "un auténtico laboratorio metodológico", ${ }^{37}$ com suas formas artísticas e modos de vida, tidos como plenos de energia espiritual que tiraria a Europa do pesadelo do materialismo capitalista.

\footnotetext{
${ }^{36}$ PLATÃO. O banquete. Tradução Cavalcante de Souza. Rio de Janeiro: Bertrand Brasil, 1997. p. 125-126.

${ }^{37}$ FORSTER, Kurt W. Introducción. In: WARBURG, Aby. El renacimiento del paganismo. Aportaciones a la historia cultural del Renacimiento europeo. Tradução Felipe Pereda et al. Madri: Alianza Editorial, 2005. p. 11-56.
} 
Ademais, a desilusão com a modernidade levara o Romantismo e depois o Simbolismo e o Decadentismo a procurarem nos ensinamentos místicos evocação para um mundo mais espiritualizado. As doutrinas místicas de Emanuel Swedenborg, Jakob Böehme, William Blake, Blaise Pascal, Novalis, entre outras, inspiraram geraçôes de poetas e literatos, desde o Romantismo, adentrando fortemente as primeiras décadas do século XX. Nesse rol, retorna o mito da androginia: na imagem da bissexualidade universal como consequência da bissexualidade divina, enquanto modelo e princípio de toda existência, o andrógino encerra a ideia de que a perfeição consiste numa unidade-totalidade. ${ }^{38} \mathrm{Em} 1938$, foi publicado na revista surrealista Minotaure o artigo de Albert Béguin ${ }^{39}$ intitulado L'androgyne, abordando o mito do andrógino desde os gregos, passando pelo Renascimento, pelos românticos alemães, até Serafita (1835) de Balzac, romance que homenageia e ilustra as doutrinas de Swedenborg sobre o andrógino, um ser perfeito, mais espiritual que carnal, imensamente erudito, dotado de faculdades mentais acima dos comuns mortais. $\mathrm{O}$ mito do andrógino retorna ao mundo moderno carregado de potência purificadora.

Em síntese, as primeiras décadas do século XX, na Europa, foram marcadas por um revival espiritual frente à crise do humanismo, percebida desde meados do século XIX. O desencanto com a ciência e a razáo como eixos explicativos da vida e da sociedade fizera emergir uma corrente de pensadores que fazia um "retorno", buscando no passado da humanidade, nos mitos e nas culturas primitivas, um elo que religasse o homem às suas origens espirituais, que lhe ensinasse novos caminhos para a criação de uma nova humanidade.

Neste movimento espiritual, grandes nomes do campo intelectual e artístico dedicaram-se, com maior ou menor intensidade, aos estudos ou práticas de ocultismo, esoterismo, cabala, a teosofia de Blavatsky e a antroposofia de Steiner, aos estudos das religiôes e das tradições místicas e suas simbologias, a Bíblia e o cristianismo antigo, o taoísmo, o budismo. Só para citar dois intelectuais que tiveram grande influência no pensamento e nas artes, na Europa, com ressonâncias no continente americano, lembro os nomes de Henri Bergson (1859-1941) e Wassily Kandinsky (1866-1944). O primeiro, filósofo da moda até 1930, concebeu o misticismo como o avesso do cientificismo. Só o misticismo poderia levar o indivíduo a romper e criar uma nova humanidade, uma nova sociedade aberta e dinâmica. ${ }^{40} \mathrm{O}$ segundo, artista que sistematizou os princípios estéticos do programa do espiritual da arte, acreditava que o artista era um visionário, encarregado de despertar a Europa, de dar-lhe esperança e novos rumos, depois de seu longo período materialista, de falta de fé, de meta e de sentido. ${ }^{41}$

\footnotetext{
${ }^{38}$ ELIADE, Mircea. Mefistófeles e o Andrógino. Tradução Ivone Castilho Benedetti. 2. ed. São Paulo: Martins Fontes, 1999.

${ }^{39}$ BÉGUIN, Albert. L'androgyne. Minotaure, n. 11, p. 10-13, primavera 1938.

${ }^{40}$ BERGSON, Henri. As duas fontes da moral e da religião. Rio de Janeiro: Zahar, 1978.

${ }^{41}$ KANDINSKY, Wassily. De lo espiritual en el arte. Tradução Genoveva Dieterich. Buenos Aires: Paidós, 2008.
} 


\section{ELOGIO DO ANACRONISMO: \\ PARA OS ANDRÓGINOS DE ISMAEL NERY}

Maria Bernardete Ramos Flores

Os problemas dos intelectuais brasileiros, nas primeiras décadas do século XX, não eram propriamente da mesma ordem dos da Europa. O Brasil ainda devia construir a modernidade, o progresso e a cultura racional e científica. Porém, os intelectuais brasileiros também fizeram um retorno ao passado, ao mundo primitivo indígena, para conhecer a "essência" da nação, encontrar uma explicação para sua história, buscar elos que religassem passado-presente-futuro. Neste movimento, o Brasil acabou por assimilar muitas das ideias europeias; bebeu na literatura e nas artes, nas teses místicas e nas crenças nos mitos; criou relaçôes de aproximaçóes com organizaçóes místicas internacionais; enfim, participou, de alguma maneira, do movimento espiritual europeu, através de movimentos literários e artísticos, que foram nomeados como "primitivistas", "espiritualistas" e "dinamistas". ${ }^{42}$

\section{O poeta visionário}

O mundo está cheio de ressonâncias. Ele constitui um cosmo de seres que exercem uma ação espiritual. A matéria morta é espírito vivo. ${ }^{43}$

Não se sabe ao certo que leituras irrigavam a imaginação de Ismael Nery. Ele "mostrou aos que o cercavam e a todos os que tomavam conhecimento de sua vida e de seu exemplo a verdadeira face do misticismo, isto é, da mais alta operação do espírito". ${ }^{44}$ Os depoimentos dos amigos informam que Nery era leitor da Bíblia, desde a infância, e que folheava constantemente livros de medicina com uma atração especial pelos tratados de anatomia. Murilo Mendes informa que o grupo de amigos, que se reunia na casa do artista, fundara-se originalmente sob "o signo de Santo Graal”, "mas nem de longe se notavam intençóes teosóficas". ${ }^{45}$ Ismael não nos deixou uma biblioteca e nem uma obra literária que pudesse nos informar sobre suas referências. Na abordagem de sua obra plástica (aproximadamente, 100 pinturas a óleo e 1.000 desenhos, aquarelas e guaches), percebe-se que o principal elemento

\footnotetext{
${ }^{42}$ Cito alguns nomes que se dedicaram ao esoterismo no Brasil, à época: Henrique José de Souza criou a Sociedade Brasileira de Eubiose, baseada nos preceitos espiritualistas difundidos pela teosofia de madame Blavastsky. Lavinia Viotti traduziu obras de Steiner e de Goethe. Farias de Brito fala sobre espiritualismo em Lanterna Verde; os poetas Jorge de Lima e Murilo Mende junto de Ismael Nery formam a tríade de poetas místicos, além de Augusto Frederico Schimdt, Godofredo Rangel, Dario Vellozo. No ensaio Sobre a estética da vida de Graça Aranha, percebe-se influência do panteísmo espiritualista de Novalis. Ângelo Guido, por sua vez, assimila a ideia de espiritualidade no elã vital do pensamento de Henri Bergson. Maria Lacerda de Moura jamais escondeu ou negou suas convicçóes espiritualistas e práticas esotéricas.

${ }^{43}$ KANDINSKY, Wassily. Olhar sobre o passado. Tradução Antônio de Pádua Danesi. São Paulo: Martins Fontes, 1991. p. 130. Originalmente, esta obra reúne trabalhos produzidos entre 1912 e 1922.

${ }^{44}$ MENDES, Murilo. Recordaçôes..., op. cit., p. 129.

${ }^{45}$ Ibid, p. 68.
} 


\section{ElOGIO DO ANACRONISMO: \\ PARA OS ANDRÓGINOS DE ISMAEL NERY}

Maria Bernardete Ramos Flores

de suas obras era a figura humana, tendo a si e a sua esposa, Adalgisa, como modelos. $\mathrm{Na}$ sua obsessão pelos autorretratos, Ismael desdobra-se em vários eus, multiplica-se, duplica-se, faceta-se em divino e satânico, em masculino e feminino, em místico e erótico, aparecendo em personalidades diferentes, num leque iconográfico que vai da imagem de um anjo a de um demônio, de uma figura mística a uma erótica, de anatomias perfeitas à distorçôes e dilaceraçôes apavorantes. Dimensão que se confirma também na sua poesia.

Eu sou a tangência de duas formas opostas e justapostas

Eu sou o que não existe entre o que existe.

Eu sou tudo sem ser coisa alguma.

Eu sou o amor entre os esposos.

Eu sou o marido e a mulher.

Eu sou a unidade infinita.

Eu sou um deus com princípio.

Eu sou o poeta!

$(E u, 1933)$

Na poética de Ismael, encontra-se aquilo que Kandinsky, em Sobre o espiritual da arte, programava para a arte: o lugar da ausência dos deuses. "Por isso, o artista se considera, às vezes como um proscrito, outras, como um deus. Às vezes, parece viver o exílio, em outras, converte-se a um tipo de divindade criadora. ${ }^{346}$ Para Kandinsky, apesar da ordem, da seguridade e dos princípios da ciência positivista, imperava um "medo latente", pressentia-se que "nuvens negras" se acumulavam, anunciando uma grande tempestade. ${ }^{47} \mathrm{O}$ artista seria, então, o homem que surge com força visionária e misteriosa. "Ele vê e ensina. Às vezes quisera libertar-se desse dom superior que frequentemente lhe é uma pesada cruz. Mas não pode. Acompanhado de burlas e ódios, arrasta o pesado e obstinado carro da Humanidade." 48

Pelo poema $E u$, que acabamos de ler, percebe-se que Ismael atribuía a si essa conjunção entre deus e poeta, e sabia que não era compreendido pelos contemporâneos: "Eu sou o poeta anônimo / Eu sou o profeta desconhecido" (Poema Eu, 1933). Negando-se a sistematizar seu pensamento, conforme depoimento de Murilo Mendes, Ismael declarava que, se o que dizia fazia algum sentido, ficaria para o futuro. "Deixo meu cérebro às geraçóes futuras" — disse ele. ${ }^{49}$ No desenho intitulado Testamento de Ismael Nery (s/d), a figura de um homem nu desloca sua cabeça (o rosto é de Ismael Nery) e a deposita sobre um pedestal, incrustado com o desenho de uma planta em brotação. Na diagonal inferior esquerda, caminham em

\footnotetext{
${ }^{46}$ KANDINSKY, Wassily. De lo espiritual en el arte, op. cit., p. 29.

${ }^{47}$ Ibid, p. 34.

${ }^{48}$ Ibid, p. 25.

${ }^{49}$ Ibid, p. 35.
} 


\section{ElOGIO DO ANACRONISMO: \\ PARA OS ANDRÓGINOS DE ISMAEL NERY}

Maria Bernardete Ramos Flores

direção do acontecimento figuras nuas (despojadas, deserdadas?), de semblantes cabisbaixos, num estado de prostração. A representação claramente destaca a ideia de uma transmissáo, no caso, a de conhecimentos — simbolizada pela cabeça — aos que virão após sua morte. "Ah, a esperança! Que é a esperança? Tenhamos esperança — aumentemos a esperança eu em Deus e vós em mim e em meus sucessores" (Testamento...).

A humanidade, como as plantas, precisa de estrume. Dos nossos corpos renasceram aqueles corpos gloriosos que encerraram as almas dos poetas, aqueles que nós já trazemos o germe. (...) Os poetas serão os últimos homens a existir, porque neles é que se manifestará a vocação transcendente do homem. (Testamento espiritual de Ismael Nery, 1933)

No autorretrato de 1927, comentado anteriormente, em que o artista sobrevoa a Baía da Guanabara, entre a imagem do Páo de Açúcar e da Torre Eiffel, a sua posição lembra a postura dos ícones de Cristo em ascensão, segundo a interpretação de Munari. ${ }^{50}$ Ainda seguindo este autor, no Autorretrato toureiro (s.d.) Ismael traz nos olhos "um misto de desespero por aquilo que faz — a luta — por se julgar de saída um vencedor e, ao mesmo tempo, a arrogância de quem se sabe vencedor". O toureiro é um predestinado. "Matar ou morrer é o lema da arena." Seu objetivo era fazer-se Deus, portanto, não importam os custos e nem as medidas, buscando aquilo que está além de suas forças, onde "o limite é sem o limite; o ver, o náo ver; e o criar, destruir". 51

Tal como no movimento europeu, Ismael Nery vislumbrou o papel importante da arte, pois chegará um dia que nem arte e nem ciência bastarão "para suprir a ânsia crescente de compreensão que a humanidade tem" (Poema Arte e artista, s.d.). Para Ismael, o artista, nestes tempos modernos, devia deixar de ser "copista da natureza", e passar a ter "a ideia justa das coisas" pelo método essencialista, "que consiste em receber sem parti-pris todas as emoçóes que se operam em nosso inconsciente" (Poema Arte e artista, s.d.). Como um predestinado, o artista devia desenvolver o germe de Deus que havia recebido no princípio da vida. E devia saber que, como predestinado, era o grande sacrificado por todos os erros dos homens.

Não quero ser Deus por orgulho.

Eu tenho esta diferença de Satã.

Quero ser Deus por necessidade, por vocação.

Não me conformo nem com o espaço e nem com o tempo,

Nem com o limite de coisa alguma.

Tenho fome e sede de tudo.

(Confissão, 1933)

\footnotetext{
${ }^{50}$ MUNARI, Luiz A. S. Ismael Nery. Pinturas e Fábulas. Dissertação (Mestrado em História) — USP, São Paulo, 1984, p. 42.

${ }^{51}$ Ibid, p. 40-41.
} 


\section{ELOGIO DO ANACRONISMO: \\ PARA OS ANDRÓGINOS DE ISMAEL NERY}

Maria Bernardete Ramos Flores

$\mathrm{O}$ revival espiritualista das primeiras décadas do século XX recebera grande impulso dos pintores (Klee, Malevich, Mondrian e Kandinsky). O almanaque Der Blaue Reiter (O cavaleiro azul), publicado em 1911 por Kandinsky e Franz Marc, como programa estético de orientação espiritualista, foi traduzido rapidamente para vários idiomas. $\mathrm{O}$ grupo pretendia uma arte que partisse das experiências, sensaçôes e sentimentos individuais, mas com um sentido universal.

$\mathrm{Na}$ arte de fin-de-siècle, depositara-se a esperança da reespiritualização da humanidade depois dos "longos anos de materialismo". Joséphin Péladan (1858-1918), romancista e esotérico que em 1891 criara a Ordem da Rosa-Cruz do Templo e do Graal e que se tornara mentor dos pintores simbolistas, desenvolvera uma teoria estética, na qual a arte tinha uma missão espiritual. Para ele, a arte deveria ressacralizar-se. A obra perfeita seria aquela que não satisfizesse apenas o intelecto, mas que fosse também um trampolim que permitisse a elevação da alma. ${ }^{52} \mathrm{O}$ filósofo argentino Luis Juan Guerrero (1896-1957), que estivera na Alemanha entre 1923 e 1928, por sua vez, também considerava que a arte sempre estivera a serviço do sagrado, e lamentava sua secularizaçáo com o mundo moderno. ${ }^{53} \mathrm{~A}$ arte sempre tivera a função de mostrar as realidades invisíveis, ao redor das quais se constituía e se perpetuava uma comunidade humana, e os homens se dirigiam às obras de arte como intermediárias entre o céu e a terra; invocava nelas as suas divindades. ${ }^{54}$

É neste contexto que Paul Klee afirmara: "A arte não reproduz o visível, mas torna visível." 55 Já que todas as coisas visíveis foram reveladas com as ciências modernas, a missão do artista era tornar visíveis as verdades latentes que conectavam o homem e o cosmos. Dessa maneira, o artista ultrapassa a função de simples criador de beleza para converter-se em visionário.

\section{O corpo humano como estojo da alma}

Deus criou duas almas.

Deu uma a Adão, outra a Eva.

Deu também a Adão e Eva

O poder de criar corpos

Para herdar as almas que Ele lhes deu.

Ismael Nery, Poema (1932)

Mário Pedrosa relata que ao sair da exposição Ismael Nery - 50 anos depois sua cabeça encheu-se de imagens que reportavam à leitura que fizera do livro Introdução ao método de

\footnotetext{
${ }_{22}$ PÉLADAN, Joséphin. Dell'androgino. Teoria amorosa - Teoria plástica (1. ed. em francês/1891). Tradução Virgilio Bondois e Gabriele Ferrero. Milão: Associazione LibriPerdutti, 2011. p. 22.

${ }^{53}$ GUERRERO, Luis Juan. Estética operatoria en sus tres direcciones. Buenos Aires: Las Cuarenta: Biblioteca Nacional de la República Argentina, 2008. p. 125.

${ }^{54}$ Ibid, p. 127.

${ }^{55}$ KLEE, Paul. Sobre a arte moderna. Tradução Pedro Süssekind. Rio de Janeiro: Zahar, 2001. p. 43.
} 
Leonardo da Vinci, de Paul Valéry. "A pintura é 'coisa mental', uma porta pela qual se entra para devassar outras aberturas para um horizonte de virtualidades. ${ }^{156}$ Como se sabe, Leonardo da Vinci fora a fonte de inspiração do poeta Paul Valéry (1871-1945). Numa resenha da tradução brasileira de 1998 da Introdução ao método de Leonardo da Vinci, Alfredo Bosi diz que "entender essa imagem de Leonardo [a imagem que dele fazia Valéry] é a via real para compreender a poética de Valéry". ${ }^{57} \mathrm{O}$ poeta tinha apenas 23 anos, em 1894, quando redigiu a primeira versão desse texto, e, no entanto, já "consegue levantar problemas originais em torno do mito literalmente submerso por 300 anos" (grifo meu) — refletiu Bosi.

De fato, muitas das representações de fin-de-siécle, como vimos anteriormente, têm origem em determinadas leituras de certos ícones do Renascimento e, especialmente, houve grande interesse pela pintura de Leonardo como síntese de um protótipo de beleza que não é nem homem e nem mulher. $\mathrm{O}$ sorriso de Monalisa encantava a todos, como um divino sorriso inteligente ${ }^{58}$ Considerava-se Leonardo o autêntico possuidor de todas as qualidades de um visionário, que o mundo materialista náo conseguira apagar. No livro de Paul Valery, que inspirou Pedrosa a estabelecer relaçôes entre Ismael Nery e Leonardo da Vinci, lê-se que se este dissecou dez cadáveres para observar a trajetória de algumas veias, devia pensar que "a organização do nosso corpo é tão maravilhosa que a alma, embora coisa divina, só com enorme custo se separa desse corpo onde habitou". A morte do corpo significaria a diminuiçáo desta "coisa divina!" (grifo do próprio Valery). ${ }^{59}$

Figura 4. Sem título, s.d., nanquim e aquarela s/papel, 36,5×25,8 cm, Masp

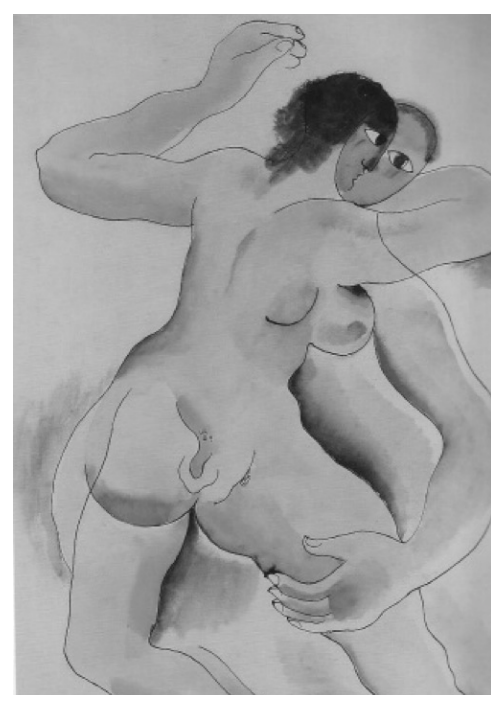

Fonte: Catálogo, 2004, p. 170.

\footnotetext{
${ }^{56}$ Catálogo, 1984, op. cit., p. 194.

${ }^{57}$ BOSI, Alfredo. Uma disciplina do olhar. Folha de S.Paulo, 12 dez. 1998. Acervo on-line. Acesso em 2 jan. 2014.

${ }^{58}$ PRAZ, Mario. La carne, la morte e il diavolo nella letteratura romântica. Milão: Alta Fedeltà, 2009. p. 292.

59 VALÈRY, Paul. Introdução ao método de Leonardo da Vinci. Lisboa: Acádia, 1979. p. 76.
} 
Ismael Nery, de igual maneira, tinha em grande conta o corpo, como morada da alma. Quando se aproximou da morte, acometido pela tuberculose e por um tumor na laringe, escreveu um poema em forma de oração, pedindo a Deus "o poder de criar corpos para as suas almas" (Oração de IN, 1933). Luiz Munari considera que, além da influência do surrealismo, Ismael tinha grande interesse pelo Renascimento, ${ }^{60} \mathrm{e}$ é quase certo que Ismael tivera contato com os desenhos de Leonardo, continua Munari, que compara seu Autorretrato místico (s/d) com a cabeça de Cristo do artista renascentista. Munari sugere, ainda, que o interesse de Ismael por vísceras e corpos dilacerados se tenha dado por algum tipo de influência dos desenhos de Leonardo. Embora, se em Leonardo tais desenhos tinham como objetivo o estudo da anatomia do corpo humano, em Nery, trata-se da desconstrução do corpo à busca de sua essência. ${ }^{61}$

Além da predileção pelos autorretratos, o par humano foi uma das obsessóes de Ismael. Os quadros nomeados como Casal, muitos deles produzem sobreposiçôes das personagens, embaralhando e mesclando cabeça, rosto, membros, órgãos genitais. O resultado é a fusão de dois corpos, masculino e feminino, a formar o par amoroso, que se dilata integrado ao cosmo, o que Ismael resolve plasticamente envolvendo as figuras em linhas que se expandem para além do corpo, ou em espécies de bolhas transparentes, minimizando o contorno. $\mathrm{Na}$ abstração do tempo e do espaço, não haveria lugar para divisôes entre sexo, erotismo e castidade, espírito e matéria, contingência e transcendência.

A fim de intensificar o processo de desdobramento das imagens, observa-se ainda que várias obras de Ismael giram em torno de um tripé: quase sempre um homem e duas mulheres. Affonso Romano de Sant'Anna, ao interpretar esses quadros, de três personagens, considera que existe mais que uma conexão ente o UM, o DOIS e o TRÊS. Existe um jogo de complementariedade de significados, uma circulação de sentidos. ${ }^{62}$ Com efeito, remetendo a pintura para o texto poético, Ismael acentua a magia do número três, dizendo: "Três mulheres pariram de mim três filhos iguais, / Samuel, Ismael e Israel”. Estes andaram pelo mundo sem saber quem era o pai. "Que para eles deixou três mulheres iguais / Com as quais tiveram três filhos (...) Os filhos de minhas noras se parecem comigo / No andar / No pensar I No falar" (Poemas pré-essencialistas, 1932).

Poderíamos, aqui, pensar no Timeu de Platão. Para que dois termos formem uma bela composição é necessário um terceiro. "Daí que o deus, quando começou a constituir o corpo do mundo, o tenha feito a partir de fogo e de terra. Todavia, não é possível que somente duas coisas sejam compostas de forma bela sem uma terceira, pois é necessário gerar entre ambas um elo que as una." ${ }^{\circ 3}$

\footnotetext{
${ }^{60}$ MUNARI, Luiz. op. cit., p. 76.

${ }^{61}$ Ibid, p. 55-56.

${ }^{62}$ SANT'ANNA, Affonso Romano de. Ismael Nery: a circularidade do um, do dois e do três. In: Catálogo, 2000, op. cit., p. 60-62.

${ }^{63}$ PLATÁO. Timeu-Critias. Tradução Rodolfo Lopes. Coimbra: Universidade de Coimbra/Centro de Estu-
} 


\section{O Cristo andrógino}

O Cristo de Ismael não era apenas uma divindade, mas também uma humanidade presente na vida cotidiana. $\mathrm{O}$ artista, preparado para recebê-lo, poderia tornar-se um instrumento de percepção das verdades espirituais. "O mundo sem mim acaba inútil. Eu sou o sucessor do poeta Jesus Cristo / Encarregado dos sentidos do universo / Eu sou o poeta Ismael Nery." E adiante ele declara: "Como o meu mestre e colega Jesus Cristo, filho da Virgem Maria / Eu também tenho uma mãe oficial — a 'Irmã Verônica.'”“4 $(E u, 1933)$. Lembro que na antroposofia de Rudolf Steiner (1861-1925) afirmava-se que toda gente poderia viver como Cristo e isto aconteceria no futuro, já que o ser humano é um ser de natureza espiritual. ${ }^{65}$

No Autorretrato mistico (s.d.) e no Autorretrato Cristo (s.d.), Ismael confunde sua própria imagem com a de Jesus Cristo. Neste último, as feiçóes de Ismael colam-se a um Cristo andrógino, o que não deve ser tomado como simples acaso ou pura experimentação artística. A androginia percorre boa parte da produçáo visual e poética de Ismael Nery, como visto anteriormente, e a imagem do Cristo andrógino não fora incomum na iconografia ocidental. Para representar a divindade de Cristo, procurou-se evitar uma determinaçáo demasiadamente humana, o que significaria dotá-lo de masculinidade. "La exigencia de los artistas coincide así, por una búsqueda de gracia y equilibrio, con ciertas especulaciones frecuentes en gnósticos y alquimistas." 66

Ângelo Guido (1893-1969), historiador da arte, italiano radicado no Brasil desde a infância, ao analisar obras de caráter andrógino de Leonardo da Vinci, tais como o São João Batista, o Baco, o anjo da Virgem do Rochedo, o S. Felipe, o S. João e o próprio Cristo da Santa Ceia, pergunta qual seria a relação entre o mito do andrógino e a pintura de Leonardo, não concordando com a interpretação psicanalítica freudiana, concernente aos impulsos de uma libido sublimada ou a expressão de um amor carnal não realizado. Para tal refutação, Guido ampara-se na obra Eros di Leonardo, de Giuseppine Fumagalli, publicada em Miláo em 1952.

O tipo andrógino, diz esta autora italiana, em figuras onde Leonardo da Vinci quis associar a beleza natural à beleza espiritual, ou a identificar a luz interior das figuras, foi resultado de uma procura consciente e lúcida da visão do significado que se encerra no mito do andrógino. Tudo leva a crer, continua a autora citada por Ângelo Guido, que Leonardo conhecia o mais importante tratado de Hermes Trimegistro, o Pimandro, de alta conside-

dos Clássicos e Humanísticos, 2011. p. 95.

${ }^{64}$ A mãe de Ismael, com a morte do marido, em 1909, tornou-se Irmã da Ordem Terceira de São Francisco, com o nome de irmã Verónica.

${ }^{65}$ STEINER, Rudolf. O cristianismo com fato mistico. Tradução Rudolf Lanz. São Paulo: Antroposófica, 1996. (Este livro reúne as conferências de Steiner proferidas durante o ano de 1902).

${ }^{66}$ LIBIS, Jean. El mito del andrógino. Tradução M. Tabuyo e A. López. Madri: Siruela, 2001. p. 147. 
ração no meio florentino à época. O trecho que deve ter dado o que pensar a Leonardo nas suas reflexóes religiosas e filosóficas deve ter sido o seguinte: "O Noûs, pai de todos os seres, sendo vida e luz, cria um homem semelhante a ele (macho e fêmea) do qual se enamora como de seu próprio filho." Noutro versículo, diz o Pimandro que macho e fêmea o homem foi criado "porque saiu de um Pai macho e fêmea". ${ }^{67} \mathrm{E}$ ainda, se Leonardo meditou sobre o mito do andrógino, como não se pode deixar de crer — Guido completa —, face às suas próprias pinturas, deve ter notado que o texto bíblico relativo à criação do homem corresponde, de certo modo, ao contexto do homem andrógino do Corpus Herméticum e da filosofia hermética dos alquimistas da sua época. ${ }^{68}$ Pois no Gênesis se lê: "E criou Deus o homem à sua imagem; à imagem de Deus o criou; macho e fêmea o criou." "69

\section{Os irmãos mitológicos}

Jean Libis, num estudo sobre o mito do andrógino, ao tratar da representação artística, diz que quando a pintura apresenta uma exigência mais realista, sejam quais forem as modalidades e os matizes, os artistas tendem muito mais a caracterizar as diferenças sexuais, como se vê em Rubens ou em Courbet, por exemplo, nos quais, "as carnes das mulheres florescem em brancuras e redondezas, enquanto que os homens têm barba, pele mais escura e traços masculinos mais definidos". Em troca, quando se anuncia uma exigência simbólica, como entre os pré-rafaelitas (Rosetti, Salomon, Burne-Jones) e simbolistas (de Gustave Moureau a Gustav Klimt), o mundo fenomênico externo tende a difundir-se diante da necessidade de produzir uma interioridade psíquica do modelo. Na série Adão e Eva, de Gustav Moreau, por exemplo, tanto Adão quanto Eva se apresentam com a mesma silhueta afilada, o mesmo rosto lânguido, a mesma cabeleira "crística", o mesmo peito miúdo. A idealização do corpo vai a par de uma idealização do desaparecimento de suas diferenças sexuais. O ideal masculino - um adolescente e náo uma mulher — e o ideal feminino - uma mulher efebizada — aparecem de forma inequívoca também nas figuras de Burne-Jones, cuja mulher na série Perseu é mais forte e decidida que seu acompanhante. ${ }^{70}$ Esse imperativo por manter o casal heterossexual, sem contudo enfatizar a diferença sexual, se verifica no quadro Arte ou as carícias (1896), um autorretrato do belga simbolista Fernand Khnopff, de aparência andrógina, junto da irmã. O rosto dele, de uma beleza feminina, está colado ao rosto da irmá, um tanto másculo, sobre o corpo de uma esfinge, um animal carnívoro. Esta obra funciona, nos diz Diego, entre outras coisas, como me-

\footnotetext{
${ }^{67}$ GUIDO, Ângelo. Simbolos e mitos na pintura de Leonardo. Porto Alegre: Sulinas, 1969. p. 79-83.

${ }^{68}$ Ibid, p. 84.

${ }^{69}$ A BÍBLIA SAGRADA. Tradução João Ferreira de Almeida. rev. e corr. São Paulo: Sociedade Bíblica do Brasil, 1995. p. 3.

${ }^{70}$ LIBIS, Jean. El mito del andrógino, op. cit., p. 147.
} 
táfora da atemporalidade: o artista ao converter a moça num duplo feminino — virgem e fêmea fatal - quis mostrar o dom espiritual elevado do andrógino, capaz de sentir o desejo sem ceder à tentação. Se o andrógino correspondesse aos avanços amorosos da esfinge deixaria de ser assexual e se converteria num ser mortal. Fernand Khnopff se situa assim no âmbito das imagens artísticas e literárias que se enraízam nas referências ao incesto no mundo clássico e nas sociedades primitivas, paralelas à ideia de preservar a raça ou como uniáo mística que explicaria o incesto inicial entre o céu e a terra. ${ }^{71}$

Dentre a obra plástica de Ismael Nery, além dos quadros nomeados como Casal ou Namorados, nos quais um homem e uma mulher, embora num processo de fusáo corporal, preservam a identificaçáo dos sexos, há outros quadros e desenhos nomeados como Duas figuras, ${ }^{72}$ que supostamente representam duas mulheres, porém, mais uma vez, os traços fisionômicos de Ismael nas tais figuras femininas dissipam a caracterização do sexo. Nos quadros Duas mulheres (s.d.) e Amantes (s.d.), há uma ambiguidade proposital. Em Duas amigas (figura 5), com certeza, vemos uma figura masculina, de aspecto andrógino, com as feiçôes dos autorretratos de Nery, e uma figura feminina, com as feiçóes dos retratos de Adalgisa, sustentando uma maçã que está prestes a ser oferecida ao parceiro, ou à parceira, já que se trata de "duas amigas". Em As irmãs (s/d), mais uma vez, aparecem duas personagens com as mesmas ambiguidades dos quadros de casais.

Figura 5. Duas amigas, s.d., óleo s/tela, 49,5×34 cm, col. Benjamin Fleider, SP.

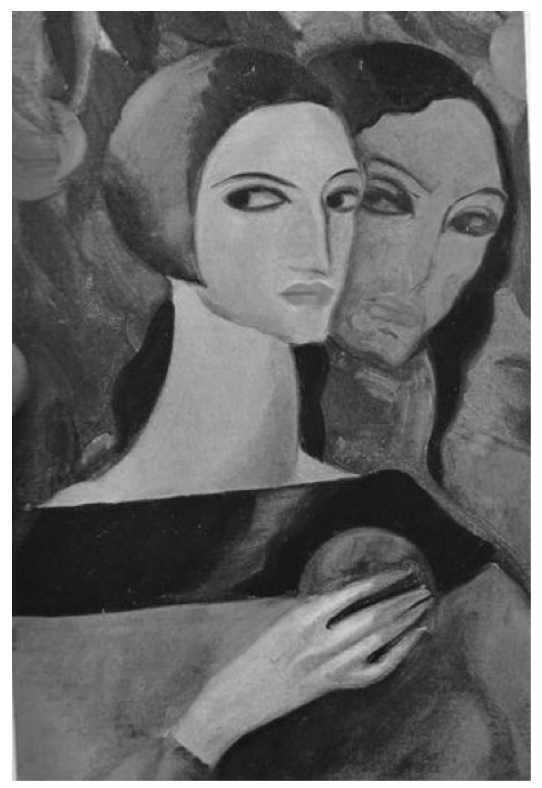

Fonte: Catálogo, 1984, p. 57.

\footnotetext{
${ }^{71}$ DIEGO, Estrella de. El andrógino sexuado. Madri: Visor, 1992. p. 69.

${ }^{72}$ Ismael costumava dar título aos seus trabalhos, já que, em certo sentido, a escrita fazia parte da composição plástica, além de tratar-se de uma obra autobiográfica. Contudo, não costumava datá-los.
} 
No quadro intitulado Narcisismo (s.d.), ${ }^{73}$ agora de corpo inteiro, vemos duas figuras de silhueta longilínea. A feminina, sedutora, aparece com um vestido transparente que the deixa os seios à mostra. Já o homem traz nos olhos a imagem de puro desejo ou devoção; a posição de suas mãos, em prece, o coloca em uma situação de servidão e fragilidade; ele não toca a moça, somente contempla sua beleza que, ao que tudo indica, é indescritível a seus olhos. No mito de Narciso, conforme a versão de Pausanias, consta que Narciso tinha uma irmã gêmea com quem se parecia demais. Os dois jovens eram muito belos, e Narciso a amava tanto que sofrera demais com a morte da jovem. Quando o rapaz viu sua própria imagem numa fonte, pensou ter visto a irmá, passando a repetir o subterfúgio para consolar sua dor, mesmo sabendo que o que via era o seu próprio rosto. "Narciso só se seduz e conquista seu poder de sedução ao desposar de maneira mimética a imagem perdida da irmá gêmea morta, restituída por seu próprio rosto." ${ }^{74}$

Ismael, que não teve irmã, escreveu o poema Ismaela (1932), no qual se lê: "A minha irmã é minha edição feminina e meu castigo /Se eu não soubesse que sou também o seu castigo / Há muito tempo que seria fratricida ou suicida."

\section{Por uma história do repetitivo?}

Para Nicole Loraux, o elogio do anacronismo é procedente para sugerir que no tempo cronológico da história se conceda um lugar aos fenômenos de repetição, que têm a ver com a "consideração sistemática das paixôes e das relaçôes com o poder, que provavelmente, aliás, são cúmplices".75

Por que fazer o elogio do anacronismo quando se é historiador? Para convidar os historiadores, talvez, a se colocar à escuta de nosso tempo de incertezas apegando-se a tudo o que ultrapassa o tempo da narração ordenada: aos embalos assim como às ilhotas de imobilidade que negam o tempo na história, mas que fazem o tempo da história. ${ }^{76}$

Em 1997, ocorrera a exposição Panorama da Arte Brasileira do Museu de Arte Moderna de São Paulo, que tinha por objetivo reunir o que de atual se produzia no Brasil. No início da mostra, o que vimos? Uma aquarela de Ismael, um casal (Sem título, s.d.) abraçado, transpassado, misturado em todas as suas partes, uma obra bem representativa do artista "maldito" do modernismo brasileiro. Para fechar a mostra, uma Monotipia de Tunga (Sem título, 1997), que apresentava igualmente o desenho de um casal erótico em processo de fusão.

\footnotetext{
${ }^{73}$ Em algumas reproduçóes, este quadro aparece com o título Casal de namorados.

${ }^{74}$ MATTAR, Denise. Ismael Nery: Além do espaço e do tempo. In: Catálogo. 2004. p. 9-23.

${ }^{75}$ LORAUX, Nicole. Elogio do anacronismo, op. cit., p. 67.

${ }^{76}$ Ibid, p. 68.
} 
Se Ismael Nery, na época em que viveu, estivera "distante de Di Cavalcanti, Tarsila do Amaral e Candido Portinari", alinhou-se, agora, "sem obstáculo à sensibilidade artística da última década do século passado, voltada como a dele, para a expressão do estranhamento do artista frente ao mundo, a partir do uso real ou metafórico do corpo" ${ }^{77}$ Foi no futuro que a obra de Ismael Nery passou a fazer sentido para a arte brasileira e a chamar o olhar de críticos e historiadores da arte. Somente na década de 1990 a obra de Ismael encontrou um espaço de diálogo com outros artistas, num "momento de incerteza e inflexão que representou o final do século XX no Brasil e no mundo". ${ }^{78}$ Lembrando Walter Benjamin, "o passado só se deixa fixar, como imagem (...) no momento em que é reconhecido." $79 \mathrm{Ou}$, citando Aby Warburg: "Cada época es capaz de ver sólo aquellos símbolos del Olimpo que puede reconocer y asimilar precisamente gracias al desarrollo de sus instrumentos de visión interiores." ${ }^{80}$

Estes objetos da história, estes acontecimentos “deslocados de seu tempo", ganham dimensão histórica ao serem abordados fora da cronologia linear, ou através de tempos impuros e justapostos. O conhecimento do passado, dizia Nietzsche, alarga-se com as imagens: "As coisas voltam eternamente a nós por elas." 81

O saber histórico jorra de fontes inexauríveis; sempre de novo e cada vez mais; o que é estrangeiro e desconexo entre si se aglomera; a memória abre todas as suas portas e no entanto ainda não está suficientemente aberta; a natureza se esforça ao máximo por receber estes hóspedes estranhos, por ordená-los e honrá-los, mas estes mesmos estão em combate entre si, e parece necessário dominar e vencer todos eles, para não perecer ela mesma, nesse combate entre eles. ${ }^{82}$

Walter Benjamin, a partir da problemática da memória levantada por Nietzsche, a partir da concepção de memória involuntária, tal como tratada por Proust, e a partir do trabalho do inconsciente, como visto por Freud, formula uma nova concepção de história, cuja temporalidade provém da experiência única entre passado e presente, apreendida pelo trabalho do historiador que escava nas profundezas da história, onde se encontra a matéria estratificada anacronicamente a qual religa o espírito humano.

\footnotetext{
${ }_{77}$ CHIARELLI, Tadeu. De volta para o futuro. A obra de Ismael Nery e a arte contemporânea. In: Catálogo. 2004. p. 171-185.

${ }^{78}$ Ibid, p. 172.

${ }^{79}$ BENJAMIN, Walter. Sobre o conceito de história, op. cit., p. 224.

${ }^{80}$ WARBURG, Aby. El renacimiento del paganismo. Aportaciones a la historia cultural del Renacimiento europeo. Tradução Felipe Pereda et al. Madri: Alianza Editorial, 2005. p. 25.

${ }^{81}$ NIETZSCHE, Friedrich. Assim falou Zaratustra. Tradução Alex Marins. São Paulo: Martin Claret, 2004. p. 172.

${ }^{82}$ Id. Da utilidade e desvantagem da história para a vida (1874). Tradução Rubens Rodrigues Torres Filho. 3. ed. São Paulo: Abril Cultural, 1983. p. 62. (Os Pensadores. Obras Incompletas.)
} 
Certamente, os adivinhos que interrogavam o tempo para saber o que ele ocultava em seu seio não o experimentavam nem como vazio nem como homogêneo. Quem tem em mente este fato poderá, talvez, ter uma ideia de como o tempo passado é vivido na rememoração; nem como vazio, nem como homogêneo. ${ }^{83}$

Aby Warburg, também leitor de Nietzsche, teve como projeto compreender o problema da longa duração das imagens, "la reaparición de las formas del arte antiguo en épocas posteriores". ${ }^{84}$ Diante dos relevos de Adolf von Hildebrand, Warburg viu, respectivamente, a sobrevivência da Antiguidade nas suas duas acentuaçóes de movimento: a tendência dionisíaca no exagero e a apolínea no autocontrole. As representaçóes de figuras "agitadas" com formas de ninfa na pintura do Renascimento, inspiradas não só na poesia, mas também na arte figurativa, da Antiguidade, suscitaram a Warburg a tese de que esses objetos em movimentos podiam ser tomados como sintoma de um “influjo de la Antigüedad”. ${ }^{5}$ Para ele, a razão pela qual a ninfa estava tão intensamente carregada de significado, na sua inesperada reaparição precisamente em meio ao mundo florentino burguês, encontra-se no fato de que esta figura tinha já um posto no imaginário dos pintores renascentistas. ${ }^{86} \mathrm{E}$ agora, na Modernidade dos finais do século XIX, a irrupção de formas do mundo antigo servia a Warburg como pedra de toque para avaliar em que medida o conflito entre as concepçóes espirituais antigas e as modernas ocupavam o pensamento contemporâneo.

En el presente trabajo me propongo comparar los conocidos cuadros mitológicos de Sandro Botticelli, El Nacimiento de Venus y La Primavera, con las representaciones equivalentes a la literatura poética y teórico-artística contemporánea con el objeto de clarificar cuáles fueron los aspectos de la Antigüedad que interesaron al artista del Quattrocento. ${ }^{87}$

A novidade aqui, como se vê, é a percepção do poder de sobrevivência da imagem. "La imagen a menudo tiene más de memoria y más de porvenir que el ser que la mira." ${ }^{88} \mathrm{~A}$ imagem está aberta ao tempo, o que implica reconhecer que ela age dentro de certa dinâmica $d a$ memória e das sobre-determinaçóes do tempo. Como metáfora desta dialética entre tempos, entre passado e presente, entre anacronia e eucronia, Didi-Huberman lança mão da mitológica Vênus Anadiômena: a deusa que navega dentro de uma vieira, sobre as espumas do mar, num movimento que lhe faz oscilar entre aparição e desaparição frente aos nossos olhos. ${ }^{89} \mathrm{E}$

${ }^{83}$ BENJAMIN, Walter. Sobre o conceito de história, op. cit., p. 232.

${ }^{84}$ FORSTER, Kurt W. Introducción, op. cit., p. 20.

${ }^{85}$ Ibid, p. 23.

${ }^{86}$ Ibid, p. 25.

${ }^{87}$ WARBURG, Aby. El renacimiento del paganismo, op. cit., p. 73.

${ }^{88}$ DIDI-HUBERMAN, Georges. Ante el tempo, op. cit., p. 32.

${ }^{89}$ DIDI-HUBERMAN, Georges. O que vemos, o que nos olha. Traduçáo Paulo Neves. São Paulo: Editora 34, 1998. p. 33. 
se Anadiômena tem sua virgindade constantemente renovada, a imagem, no seu "nascer de novo", tem sua força imagética revivida: trata-se do nachleben, conceito warburguiano.. A Anadiômena reapareceu no Nascimento da Vênus (1483) de Botticelli, depois de atravessar a Idade Média "escondida" por baixo das vestes de Maria. ${ }^{90}$

Jacques Rancière, já citado, reflete sobre a tese de Lucien Febvre, segundo a qual não se pode afirmar que as formas das paródias rabelesianas encobrem uma empresa demolidora da religiáo cristã como tal. Fazer de Rabelais um incrédulo é falso porque anacrônico, segundo Febvre. Seria tornar contemporâneo do tempo de Rabelais um pensamento que náo pertence a esse tempo, que era o tempo em que o Cristianismo organizava "toda" a vida da sociedade. "O tempo de Rabelais não lhe permitia não crer, porque a forma do tempo é idêntica à forma mesma da crença." ${ }^{11}$ Ser um objeto da história, portanto, para Lucien Febvre, "é crer na crença de 'seu tempo', pertencer ao seu tempo sob o modo da crença, sob o modo de adesão indefectível”. ${ }^{92}$

Rancière conclui disto que o anacronismo condenado pela École des Annales não é a confusão de data, mas a confusão das épocas. Ora, as épocas não são simples recortes no contínuo das sucessôes - diz o filósofo. Elas marcam regimes de verdade específicos, relaçóes da ordem do tempo com a ordem do que está no tempo. Trata-se de pensar o próprio tempo como princípio de imanência subsumindo todos os fenômenos numa lei de interioridade. De modo que a verdade da história é a imanência do tempo como princípio de copresença e de copertencimento dos fenômenos. ${ }^{93}$ A história que não permite o anacronismo "desvaloriza" a atividade do sujeito individual, ou, como diz Rancière, nela não há lugar para a heresia, ${ }^{94}$ ou não há lugar para os dissensos, como nos regimes democráticos modernos: onde tudo se concerta para o consenso não há lugar para a política. ${ }^{95}$ Esta história que condena o anacronismo segue os princípios de totalidade, que se transforma pelo princípio de autorregulação.

A proposta de Rancière, portanto, é a de que nos liberemos da racionalidade histórica e que é preciso, inclusive, "desconstruir" o conceito de anacronismo, pois, este parte do princípio da relaçấo entre o tempo da existência na terra e o tempo da eternidade, da copresença das possibilidades da experiência no tempo. "O conceito de anacronismo é anti-histórico, pois oculta as condiçôes mesmas de toda historicidade."

\footnotetext{
${ }^{90}$ HAGEN, Rose-Marie; HAGEN, Rainer E. Los secretos de las obras de arte. Londres: Taschen, 2003. p. 95.

${ }^{91}$ RANCIÈRE, Jacques. O conceito de anacronismo, op. cit., p. 33.

${ }^{92}$ Ibid, p. 35.

${ }^{93}$ Ibid, p. 36.

${ }^{4}$ RANCIÉRE, Jacques. Os nomes da história. Tradução Eduardo Guimarães e Eni Orlandi. São Paulo: EDUC/Pontes, 1994.

${ }^{95}$ RANCIÉRE, Jacques. Dissenso. Tradução Paulo das Neves. In: NOVAIS, Adauto (Org.). A crise da razão. São Paulo: Companhia das Letras, 1996. p. 367-382.
} 


\section{ELOGIO DO ANACRONISMO: \\ PARA OS ANDRÓGINOS DE ISMAEL NERY}

Maria Bernardete Ramos Flores

Há história na medida em que os homens não se "assemelham" ao seu tempo, na medida em que eles agem em ruptura com o "seu" tempo, com a linha de temporalidade que os coloca em seus lugares impondo-lhes fazer do seu tempo este ou aquele "emprego". Mas essa ruptura mesma só é possível pela possibilidade de conectar essa linha de temporalidade com outras, pela multiplicidade de linhas de temporalidade em "um" tempo. ${ }^{96}$

Assim, o ponto de partida da ciência histórica, na opinião de Rancière, deve ser constituído pelas manifestaçóes de linhas heterogêneas de temporalidade presentes em "um" mesmo momento. $\mathrm{O}$ anacronismo como conceito deve ser rejeitado por encobrir a metafísica do tempo: do nó que amarra o tempo abstrato da eternidade ao tempo concreto da experiência humana. Ora, é preciso perceber que existem modos de conexão entre "séries temporais heterogêneas" que podem, positivamente, ser vistas como "anacronias": “acontecimentos, noçôes, significaçôes que tomam o tempo de frente para trás, que fazem circular sentidos de uma maneira que escapa a toda contemporaneidade, a toda identidade do tempo com 'ele mesmo." 97 A “anacronia” de uma palavra, ${ }^{98}$ de um acontecimento, de uma série de significados que permitem direçôes, saltos ou conexôes temporais, é o que dá sentido ao "fazer" histórico. "A multiplicidade das linhas de temporalidades, dos sentidos mesmo de tempo incluídos em um 'mesmo' tempo, é a condição do agir histórico.” 99

\section{Referências bibliográficas}

A BÍBLIA SAGRADA. Tradução João Ferreira de Almeida. rev. e corr. São Paulo: Sociedade Bíblica do Brasil, 1995.

AGAMBEN, Giorgio. O que é o contemporâneo. Tradução Vinícios N. Honesko. Chapecó, SC: Argos, 2009.

AMARAL, Aracy (Cur.). Catálogo: Ismael Nery — 50 anos depois. São Paulo: Museu de Arte Contemporânea da Universidade de São Paulo, 1984.

- Textos do Trópico de Capricórnio. São Paulo: Ed. 34, 2006. v. 1.

BÉGUIN, Albert. L'androgyne. Minotaure, n. 11, p. 10-13, primavera 1938.

BENJAMIN, Walter. Sobre o conceito de história. In: Obras escolhidas: Magia e Técnica, Arte e Política. Tradução Sérgio Paulo Rouanet. São Paulo: Brasiliense, 1987.

BENTO, Antônio. Ismael Nery. São Paulo: Gráficos, 1993.

\footnotetext{
${ }^{96}$ RANCIÈRE, Jacques. O conceito de anacronismo, op. cit., p. 47.

${ }^{97}$ Ibid, p. 49.

${ }^{98}$ Rancière mostrou em Noite dos proletários (1988) que a palavra proletária já existia na Roma arcaica. Como e por que esta palavra serviu para designar a classe trabalhadora moderna?

${ }^{99}$ RANCIÈRE, Jacques. O conceito de anacronismo, op. cit., p. 49.
} 
BERGSON, Henri. As duas fontes da moral e da religião. Rio de Janeiro: Zahar, 1978.

BOSI, Alfredo. Uma disciplina do olhar. Folha de S.Paulo, 12 dez. 1998. Acervo on-line. Acesso em 2 jan. 2014.

BURLAMAQUI, Jorge. Abstração do tempo e do espaço. A Ordem, Rio de Janeiro, p. 193195, fev./mar. 1935.

CHIARELLI, Tadeu. De volta para o futuro. A obra de Ismael Nery e a arte contemporânea. In: MATTAR, Denise (Org. e Cur.). Catálogo: Ismael Nery. Rio de Janeiro: Banco Pactual S.A./Lei de Incentivo à Cultura/Ministério da Cultura, 2004. - Pintura não é só beleza. A crítica de arte de Mário de Andrade. Florianópolis: Letras Contemporâneas, 2007.

DIDI-HUBERMAN, Georges. Ante el tempo. Historia del arte y anacronismo de las imágenes. Tradução Antonio Oviedo. Buenos Aires: Adriana Hidalgo, 2011.

- La condition des images. Entretian avec Frédéric Lambert et François Niney. 2007. p. 12. Disponível em: <http://documents.irevues.inist.fr/bitstream/handle/2042/28239/2007_19_06.pdf?sequence=1>. Acesso em: 28 jan. 2014.

. O que vemos, o que nos olha. Tradução Paulo Neves. São Paulo: Editora 34, 1998.

DIEGO, Estrella de. El andrógino sexuado. Madri: Visor, 1992.

ELIADE, Mircea. Mefistófeles e o Andrógino. Tradução Ivone Castilho Benedetti. 2. ed. São Paulo: Martins Fontes, 1999.

FORSTER, Kurt W. Introducción. In: WARBURG, Aby. El renacimiento del paganismo. Aportaciones a la historia cultural del Renacimiento europeo. Tradução Felipe Pereda et al. Madri: Alianza Editorial, 2005.

FUENTES, Carlos. Federico em sua sacada. Tradução Carlos Nougué. Rio de Janeiro: Rocco, 2013.

GUERRERO, Luis Juan. Estética operatoria en sus tres direcciones. Buenos Aires: Las Cuarenta: Biblioteca Nacional de la República Argentina, 2008.

GUIDO, Ângelo. Simbolos e mitos na pintura de Leonardo. Porto Alegre: Sulinas, 1969.

HAGEN, Rose-Marie; HAGEN, Rainer E. Los secretos de las obras de arte. Londres: Taschen, 2003.

HARTOG, François. Tempo e Patrimônio. Vária História, Belo Horizonte, v. 22, n. 36, p. 261-273, jul./dez. 2006.

HUYSSEN, Andreas. Seduzidos pela memória. Rio de Janeiro: Aeroplano, 2004.

KANDINSKY, Wassily. Olhar sobre o passado. Tradução Antônio de Pádua Danesi. São Paulo: Martins Fontes, 1991.

. De lo espiritual en el arte. Tradução Genoveva Dieterich. Buenos Aires: Paidós, 2008.

KLEE, Paul. Sobre a arte moderna. Tradução Pedro Süssekind. Rio de Janeiro: Zahar, 2001, 
p. 43.

LIBIS, Jean. El mito del andrógino. Tradução M. Tabuyo e A. López. Madri: Siruela, 2001. LORAUX, Nicole. Elogio do anacronismo. In: NOVAIS, Adauto (Org.). Tempo e História. São Paulo: Companhia das Letras, 1992.

MARTON, Scarlet. Extravagâncias: Ensaios sobre a filosofia de Nietzsche. São Paulo: Discurso Editorial; Unijuí, 2000.

MATE, Reyes. Meia-noite na história. Comentários às teses de Walter Benjamin. Tradução Nélio Schneider. São Leopoldo, RS: Unisinos, 2011.

MATTAR, Denise (Cur.). Catálogo: Ismael Nery — 100 anos: a poética de um mito. São Paulo: Fundação Armando Álvares Penteado, 2000.

(Org. e Cur.). Catálogo: Ismael Nery. Rio de Janeiro: Banco Pactual S.A./Lei de Incentivo à Cultura/Ministério da Cultura, 2004.

MENDES, Murilo. Recordaçóes de Ismael Nery. São Paulo: USP/Giordano, 1996.

MUNARI, Luiz A. S. Ismael Nery. Pinturas e Fábulas. Dissertação (Mestrado em História) — USP, São Paulo, 1984,

NIETZSCHE, Friedrich. Assim falou Zaratustra. Tradução Alex Marins. São Paulo: Martin Claret, 2004.

- Da utilidade e desvantagem da história para a vida (1874). Tradução Rubens Rodrigues Torres Filho. 3. ed. São Paulo: Abril Cultural, 1983. (Os Pensadores. Obras Incompletas.)

PÉLADAN, Joséphin. Dell'androgino. Teoria amorosa — Teoria plástica (1. ed. em francês/1891). Tradução Virgilio Bondois e Gabriele Ferrero. Milão: Associazione LibriPerdutti, 2011.

PINHEIRO FILHO, Fernando Antonio. El modernismo y la formación del intelectual católico en el Brasil. In: ALTAMIRANO, Carlos. Historia de los intelectuales en América Latina II. Buenos Aires: Katz Editores, 2010.

PLATÃO. O banquete. Tradução Cavalcante de Souza. Rio de Janeiro: Bertrand Brasil, 1997. . Timeu-Critias. Tradução Rodolfo Lopes. Coimbra: Universidade de Coimbra/Centro de Estudos Clássicos e Humanísticos, 2011.

PRAZ, Mario. La carne, la morte e il diavolo nella letteratura romântica. Milão: Alta Fedeltà, 2009.

RANCIÈRE, Jacques. Dissenso. Tradução Paulo das Neves. In: NOVAIS, Adauto (Org.). $A$ crise da razão. São Paulo: Companhia das Letras, 1996.

- O conceito de anacronismo e a verdade do historiador. Tradução Mônica Costa Netto. In: SALOMON, Marlon (Org.). História, verdade e tempo. Chapecó: Argos, 2011. 
. Os nomes da história. Tradução Eduardo Guimarães e Eni Orlandi. São Paulo: EDUC/Pontes, 1994.

RICOEUR, Paul. A memória, a história, o esquecimento. Tradução Alain François. Campinas: Unicamp, 2007.

SANT'ANNA, Affonso Romano de. Ismael Nery: a circularidade do um, do dois e do três. In: MATTAR, Denise (Cur.). Catálogo: Ismael Nery — 100 anos: a poética de um mito. São Paulo: Fundação Armando Álvares Penteado, 2000.

STEINER, Rudolf. O cristianismo com fato mistico. Tradução Rudolf Lanz. São Paulo: Antroposófica, 1996.

VALÈRY, Paul. Introdução ao método de Leonardo da Vinci. Lisboa: Acádia, 1979.

WARBURG, Aby. El renacimiento del paganismo. Aportaciones a la historia cultural del Renacimiento europeo. Tradução Felipe Pereda et al. Madri: Alianza Editorial, 2005. 